\title{
Fluvial lakes affect on phosphorus and potassium concentrations in the Samica Stęszewska River
}

\author{
Agnieszka E. Lawniczak ${ }^{1}$, Janina Zbierska ${ }^{2}$, Sylwia Machula ${ }^{3}$, Adam Choiński ${ }^{4}$ \\ ${ }^{1}$ Poznan University of Life Sciences, Department of Ecology and Environmental Protection, Piatkowska 94C, 60-649 Poznan, Poland, \\ email: lawnic@up.poznan.pl (corresponding author) \\ ${ }^{2}$ Poznan University of Life Sciences, Department of Ecology and Environmental Protection, Piatkowska 94C, 60-649 Poznan, Poland, \\ email: zbier@up.poznan.pl \\ ${ }^{3}$ West Pomeranian University of Technology, Department of Hydrochemistry and Water Protection, Kazimierza Królewicza 4, 71-550 \\ Szczecin, Poland, e-mail: sylwia.machula@zut.edu.pl \\ ${ }^{4}$ Institute of Physical Geography and Environmental Planning, Adam Mickiewicz University, Dzięgielowa 27, 61-680 Poznań, Poland, \\ e-mail: choinski@amu.edu.pl
}

\begin{abstract}
The aim of the study was to evaluate the effect of shallow lakes on reactive, total phosphorus and potassium concentrations in the river water and analyse the effect of changes in water retention in lake on nutrient concentrations in river waters. The study was carried out in the Samica Steszewska River. This is lowland river, which flows through two polymictic lakes. The study site is located in the Wielkopolska Lowland, Central-west Poland. Water samples were collected at depths of $0.5 \mathrm{~m}$ below the water surface. Reactive, total phosphorus and potassium were analysed monthly by standard methods. The study was carried out from January to December 1999-2002 (period with high water retention), 2005-2008 (period with low water retention), at four control points. Sites were located at the inflow and outflow of the Samica Stęszewska River into and out of Niepruszewskie and Tomickie Lakes. From 1974 to 2002, Lake Niepruszewskie was regulated at its outlet by a weir. In 2002, the water level was reduced. Changes of water retention in Niepruszewskie Lake influenced water discharge of the Samica Stęszewska River. The results indicate that changes in water retention have significantly influenced water quality in the river, particularly total and reactive phosphorus concentrations; however, this influence was not observed in respect to potassium concentrations. Nutrient concentrations in river strongly depend on water quality of the lake ecosystem and their buffering capacity. Additionally, by improving water quality, increased oxygen concentrations, and decreasing dissolved nutrient concentrations, as well as increased amplitude of water level fluctuations in lakes may increase P-fixation rates in outlet streams.
\end{abstract}

Key words: lake-river systems, reactive and total phosphorus, potassium concentration

\section{Introduction}

Flow rivers have significant positive or negative influence on lake ecosystem or inversely, these ecosystems may also impact flow rivers (Hillbricht-Ilkowska 1999; Marcarelli and Wurtsbaugh 2007). Lakes, in relations to streams, have longer hydraulic retention times and, are characterised by domination of sedimentation and accumulation processes over erosion as well as advantage of autochthonous material over allochthonous, etc. (Hillbricht-Ilkowska 1999; Kling at al. 2000; Neal et al. 2008). However, these differences are not always sharp and, still, it is unclear how natural lakes are ecologically linked with their inlet and outlet rivers (Hillbricht-Ilkowska 1999; Marcarelli and Wurtsbaugh 2007). This interaction may have differ- entiated strength and might change, for example, due to the modification of nutrient availability (Kling et al. 2000), hydrology or morphology (Arp et al. 2006).

In last decade, many water bodies have been affected by hydraulic engineering constructions, which significantly changed hydrology and biogeochemical processes in lakes and rivers. This effect has been strengthened by point sources, particularly, from waste water discharges, which are major sources of phosphorus (Neal et al. 2006; Bowes et al. 2005).

However, recently the most predominant sources of water pollutions are diffuse inputs, of which agriculture is considered to be the predominant source, particularly of nitrate and potassium (Neal et al. 2006, 2008). Potassium pollution is also caused by the waste water discharge from industrial activities and is one of 
the predominant ion of mineral pollutions in surface water (Manahan 2005). All these factors may significantly change the character of interactions between lakes and streams, for example, directly or indirectly in respect to nitrogen, phosphorus and potassium uptake, removal and release mechanisms. However, our knowledge about these interactions is still insufficient.

The objective of this research project was: 1 ) to evaluate the effect of shallow lakes on reactive, total phosphorus and potassium concentrations in the water river 2) to analyse the effect of changes in water retention in the lake on nutrient concentrations in river waters.

\section{Study site description}

The study was carried out in the Samica Stęszewska River, located about $27 \mathrm{~km}$ west from Poznan, Poland. The length of the river is $37.87 \mathrm{~km}$. The river flows from the source located near Ceradz Kościelny, across cultivated agricultural land and flows through shallow Lake Niepruszewskie (3.05 m average depth), then Lake Tomickie (1.1 m average depth) and following lakes to the Mosiński Canal. From 1974 to 2002, the Niepruszewskie Lake was regulated at its outlet by a weir for irrigation purposes. The decreased of water level in the lake influenced on water discharge in the Samica Stęszewska River (Zbierska and Ławniczak 2006).

\section{Methods}

The study was carried out from January to December 1999-2002 and 2005-2008 at four stations. Sites were located at the inflow (S1-LN, S3-LT) and outflow (S2-LN, S4-LT) of the Samica Stęszewska River into and out of Lake Niepruszewskie (LN) and Tomickie (LT), respectively. Water samples were taken monthly at depths of $0.5 \mathrm{~m}$ below the water surface. A $100-\mathrm{ml}$ aliquots of each sample were filtered through a $0.45 \mu \mathrm{m}$ cellulose nitrate membrane. The filtered and unfiltered samples were analysed for soluble reactive phosphorus (SRP) and total phosphorus (TP) (Murphy and Riley 1962), respectively, using a spectrophotometric method (HACH 2400) in the laboratory of the Department of Ecology and Environmental Protection, Poznan University of Life Sciences, within 6 hours of sampling. Potassium concentrations $(\mathrm{K})$ were measured with flame emission spectroscopy (Sherwood Model 425), in the laboratory of the Depart- ment of Agricultural Chemistry, Poznan University of Life Sciences.

The effects of locations and months or periods (one: 1999-2001 with high water retention in Lake Niepruszewskie, and second: 2005-2008 with lower water retention in Lake Niepruszewskie) on the reactive, total phosphorus and potassium concentrations in the water were analyzed with factorial three-way ANOVA. Data were log-transformed to obtain normally distributed residuals with equal variances, the nutrients were compared pairwise using the Tukey HSD test (alpha $=0.05$ ) to determine whether lakes influenced water quality in the river. All analyses were performed using Statistica (StatSoft, Poland).

\section{Results}

Soluble reactive phosphorus concentrations significantly varied between the studied control sites and between months (Fig. 1, 2, Table 1). The highest concentrations and variations were measured in the Samica Stęszewska inflow to Lake Nieruszewskie, during two studied periods. The highest SRP concentrations in the inflow were observed from June to August (varied between $0.25-0.57 \mathrm{mg} \mathrm{P}-\mathrm{PO}_{4} \mathrm{dm}^{-3}$ ) during high water retention (1999-2001) (Fig. 1a), and in August and September $\left(0.31\right.$ and $0.51 \mathrm{mg} \mathrm{P}-\mathrm{PO}_{4} \mathrm{dm}^{-3}$, respectively), during lower water retention in the lake (20052008) (Fig. 1b). During the remaining studied months, phosphorus concentrations did not differ significantly between the inflow into and outflow from the lake (Fig. 1a, 1b). At the outflow of Lake Niepruszewskie, SRP concentrations ranged between 0.01-0.15 mg $\mathrm{P}-\mathrm{PO}_{4} \mathrm{dm}^{-3}$, except in July, during the second period. Thus, a strong increase was observed.

A different relation was noted in the inflow into and outflow of Lake Tomickie. The average SRP concentrations varied from 0.02 to $0.24 \mathrm{mg} \mathrm{P}_{-} \mathrm{PO}_{4} \mathrm{dm}^{-3}$ at both sites throughout the studied years (Fig. 2). In the inflow into Lake Tomickie, the only sharp increase was observed in January $\left(0.24 \mathrm{mg} \mathrm{P}_{-} \mathrm{PO}_{4} \mathrm{dm}^{-3}\right)$ during high water retention in Lake Niepruszewskie (Fig. 2a). During low water retention in Lake Niepruszewskie, only in September, reactive phosphorus concentrations were significantly higher $\left(0.20 \mathrm{mg} \mathrm{P}^{-} \mathrm{PO}_{4} \mathrm{dm}^{-3}\right)$ in comparison with the inflow into Lake Tomickie (Fig. 2b).

Similar variations of total phosphorus concentrations like those observed for reactive phosphorus concentrations occurred at the inflow into and outflow from Lake Niepruszewskie. Total phosphorus con- 
Table 1. Results of the ANOVA testing of the effects of the time and site on reactive phosphorus, total phosphorus and potassium concentrations. All parameters were ln-transformed. Data are $F$-ratios and significance levels given as ${ }^{\star * *}, p<0.001{ }^{* *}, p<0.01 ;{ }^{\star}, p<0.05$; ns, $p \geq 0.05$. The time effect included months and two periods - first with high water retention in Lake Niepruszewskie (1999-2001), second with reduction of water retention in Lake Niepruszewskie (2005-2008)

\begin{tabular}{|c|c|c|c|c|c|c|c|c|c|c|}
\hline \multirow{2}{*}{ Variable } & & \multicolumn{3}{|c|}{ Soluble reactive phosphorus } & \multicolumn{3}{|c|}{ Total phosphorus } & \multicolumn{3}{|c|}{ Potassium } \\
\hline & df & $\mathrm{F}$ & p & Sig. & $\mathrm{F}$ & $p$ & Sig. & $\mathrm{F}$ & $\mathrm{p}$ & Sig. \\
\hline Control point & 3 & 27.605 & .000 & $* * *$ & 8.738 & .000 & $* * *$ & 23.999 & .000 & *** \\
\hline Month & 11 & 3.936 & .000 & $* * *$ & 3.820 & .000 & $* * *$ & 2.416 & .010 & ** \\
\hline Point*month & 33 & 1.274 & .162 & ns & .990 & .490 & ns & 3.067 & .000 & $* * *$ \\
\hline Period & 3 & 29.985 & .000 & $* * *$ & 9.725 & .002 & ** & & & \\
\hline Point ${ }^{*}$ period & 9 & 5.587 & .001 & ns & 1.956 & 0.124 & ns & & & \\
\hline
\end{tabular}

a)

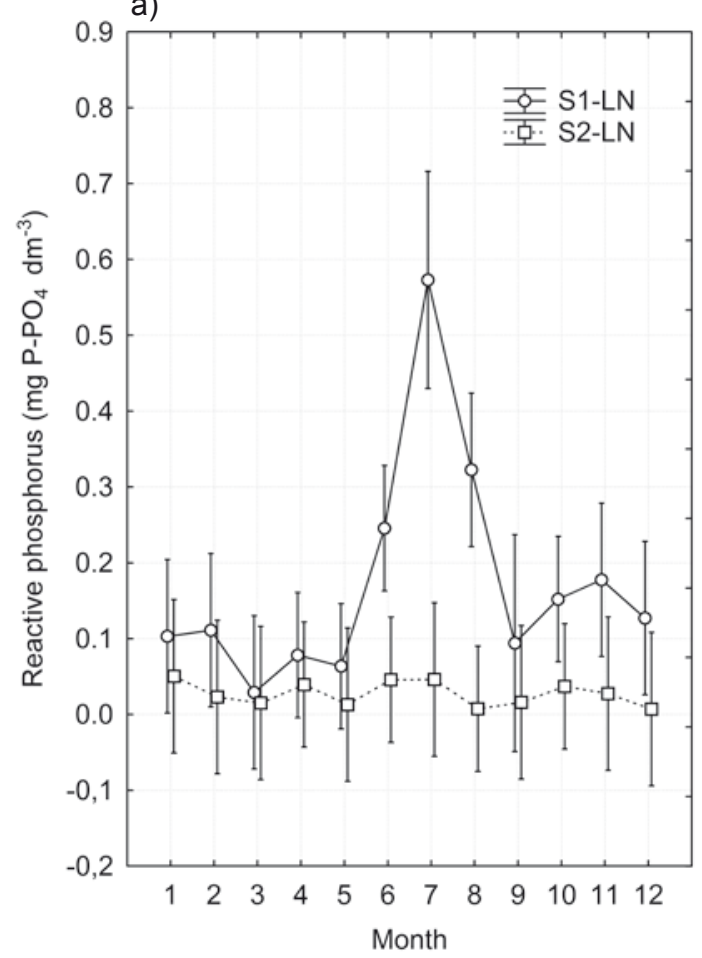

b)

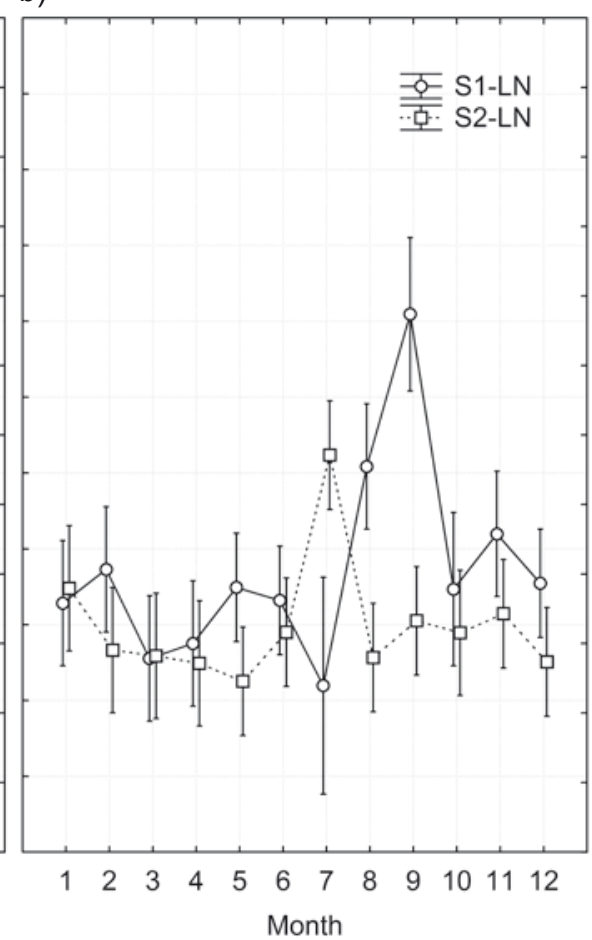

Fig. 1. Monthly soluble reactive phosphorus (SRP) concentrations in the Samica Stęszewska River at the inflow (S1-LN) and outflow (S2-LN) of Lake Niepruszewskie during: a - high water retention, b - low water retention in Lake Niepruszewskie. The plot indicates mean value \pm standard error

centrations were the highest at the inflow of Samica Stęszewska into Lake Niepruszewskie and at the outflow from Lake Tomickie (Fig. 3, 4). The highest values were noted during summer time, which varied from $0.51 \mathrm{mg} \mathrm{P} \mathrm{dm}^{-3}$ in June to $0.59 \mathrm{mg} \mathrm{P} \mathrm{dm}^{-3}$ in July in the first site (inflow into Lake Niepruszewskie), and from $0.39 \mathrm{mg} \mathrm{P} \mathrm{dm}^{-3}$ August to $0.45 \mathrm{mg} \mathrm{P} \mathrm{dm}^{-3}$ in September, in the fourth site (outflow from Lake Tomickie).
The reduction of water retention had a significant influence on total phosphorus concentrations in the river (Table 1, Fig. 2b, 3b). At the outflow from Lake Tomickie, phosphorus concentrations were significantly higher compared to the concentrations at the inflow and increased twofold after water level reduction. The highest values were recorded in years 2005-2008, average $0.22 \mathrm{mg} \mathrm{P} \mathrm{dm}^{-3}$, when the water re- 

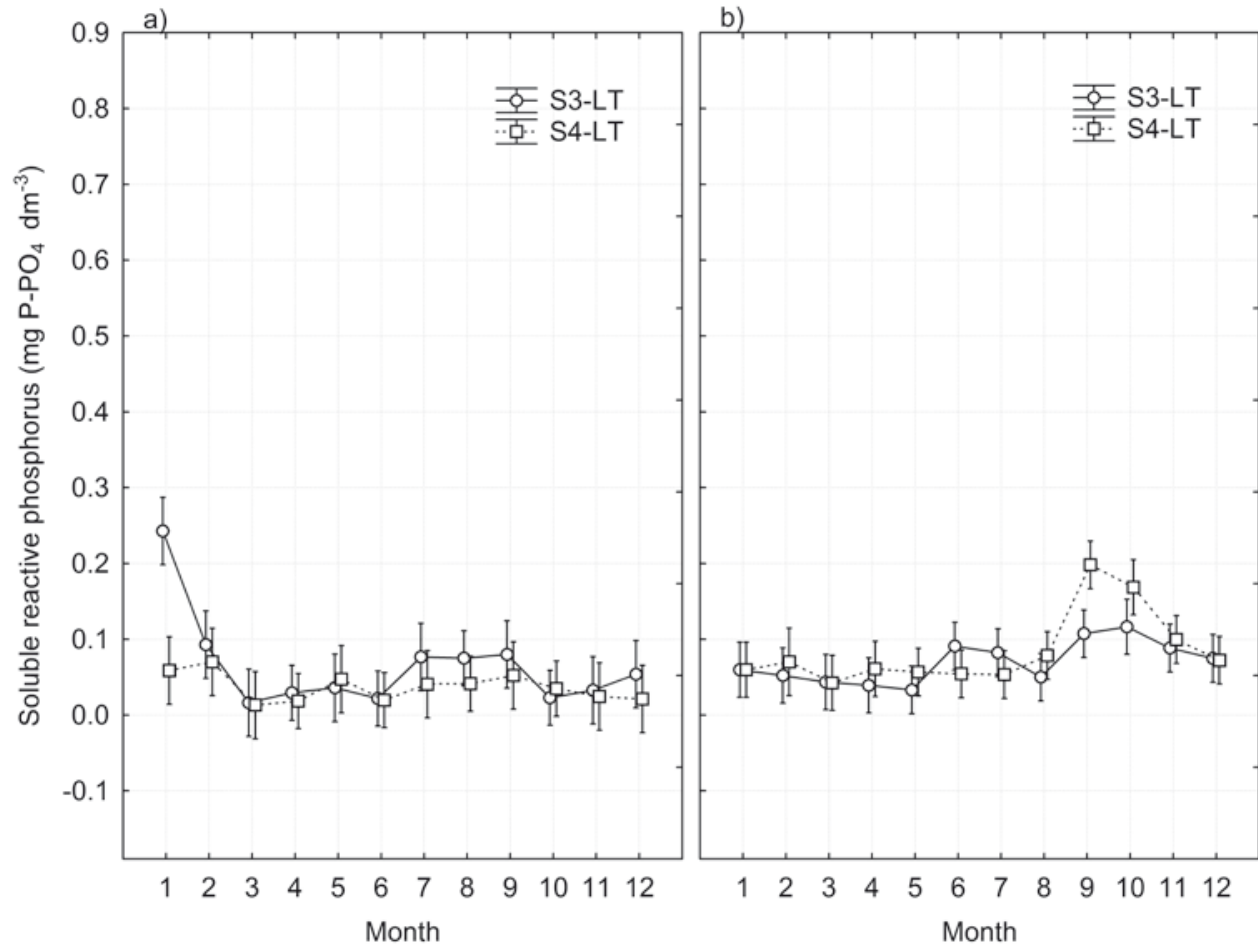

Fig. 2. Monthly soluble reactive phosphorus (SRP) concentrations in the Samica Stęszewska River at the inflow (S3-LT) and outflow (S4-LT) of Lake Tomickie during: a - high water retention, b - low water retention in Lake Niepruszewskie. The plot indicates mean value \pm standard error

a)

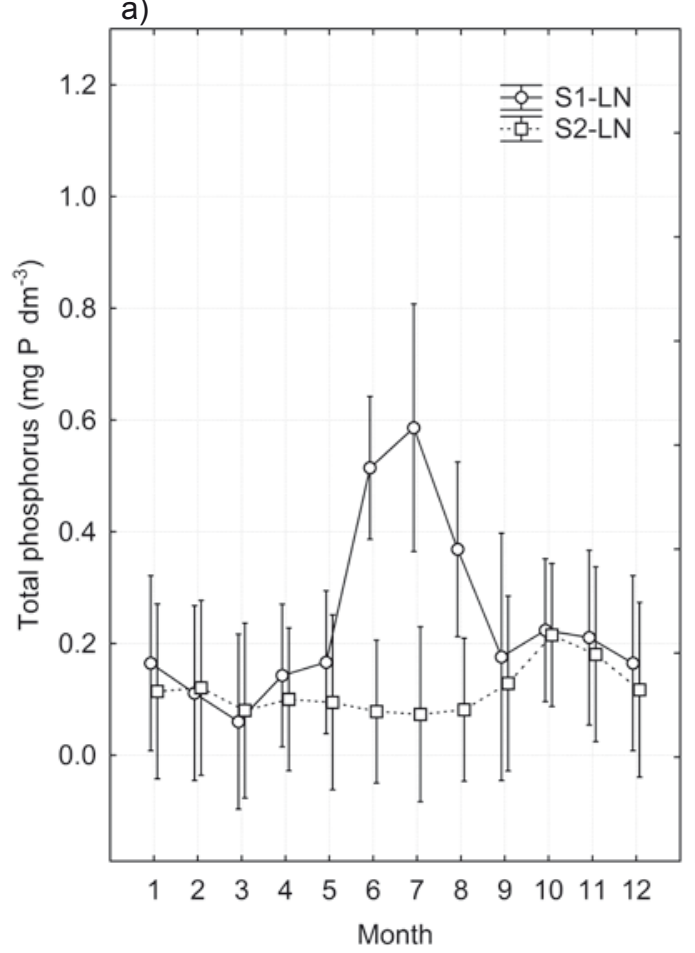

b)

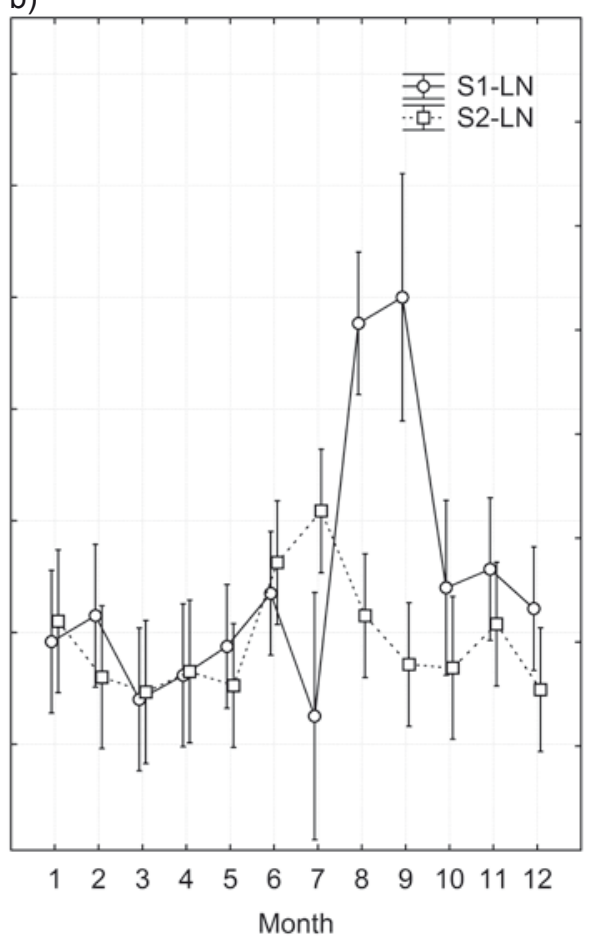

Fig. 3. Monthly total phosphorus concentrations in the Samica Stęszewska River at the inflow (S1-LN) and outflow (S2-LN) of Lake Niepruszewskie during: a - high water retention, b - low water retention in Lake Niepruszewskie. The plot indicates mean value \pm standard error 

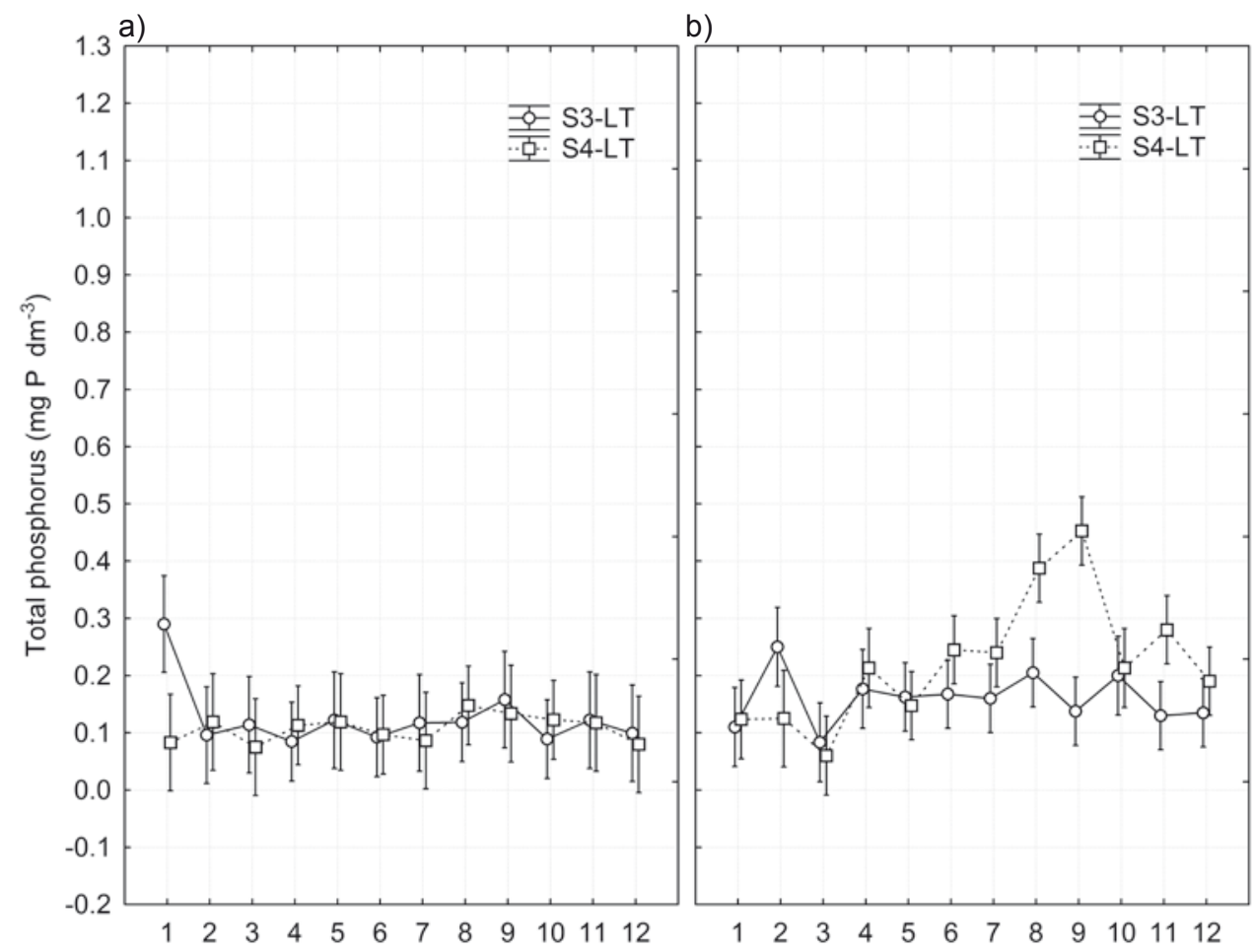

Fig. 4. Monthly total phosphorus concentrations in the Samica Stęszewska River at the inflow (S3-LT) and outflow (S4-LT) of Lake Tomickie during: a - high water retention, $\mathrm{b}$ - low water retention in Lake Niepruszewskie. The plot indicates mean value \pm standard error

tention was higher, in comparison with 1999-2001, average $0.11 \mathrm{mg} \mathrm{P} \mathrm{dm}^{-3}$. Particularly, threefold increases were observed during non-vegetation season (from August to December) which varied from 0.07 to 0.15 $\mathrm{mg} \mathrm{P} \mathrm{dm}{ }^{-3}$ during the first of the analysed periods and from 0.19 to $0.45 \mathrm{mg} \mathrm{P} \mathrm{dm}^{-3}$, during the second one).

Potassium concentrations varied significantly between the control points and months (Table1, Fig. $5 \mathrm{a}, \mathrm{b}, 6 \mathrm{a}, \mathrm{b})$. The strongest differences were noted at the inflow of the Samica Stęszewska River into the second lake during non-growing seasons in years 2005-2008. During this period, potassium differed from 5.7 to 8.0 $\mathrm{mg} \mathrm{K} \mathrm{dm}{ }^{-3}$. At the outflow from Lake Niepruszewskie, during autumn time (from September to December), significant increases of potassium concentrations were observed. Differences of $\mathrm{K}$ concentrations between periods and sites were not significant (Table 1).

\section{Discussion}

Our results showed a significant influence of lake ecosystems on reactive and total phosphorus as well as potassium concentrations in the river water. The reduction in water level fluctuations had a minor effect on the analysed nutrient variations in the river, except for total phosphorus concentrations. The most significant effect of shallow lakes on the river was observed in aspect of phosphorus concentrations; however, this effect varied between two lakes. Lake Niepruszewskie played a role in phosphorus sink. Very high concentrations of reactive and total phosphorus were observed at the inflow of the river to the lake in comparison with the outflow. Samica Stęszewska River flows into Lake Niepruszewskie through a wide littoral zone to the open water. This zone plays a significant role in nutrient storage in the lake (Hillbricht-Ilkowska 1999; Lawniczak et al. 2006; Lawniczak 2010) which significantly uptake nutrient from sediment and water. On the other hand, high phosphorus concentrations in the inflow were measured also probably due to low-velocity during summer time and low buffering capacity of the sediment. Our results contradict the results of HillbrichtIlkowska (1999) and Bowes et al. (2003), who observed high TP retention values in the lake and rivers during spring or autumn time. This situation was caused by intensive in-lake production or retention by within sediment deposition, particularly in low-velocity rivers (Bowes and House 2001). Subsequent remobilisation of 

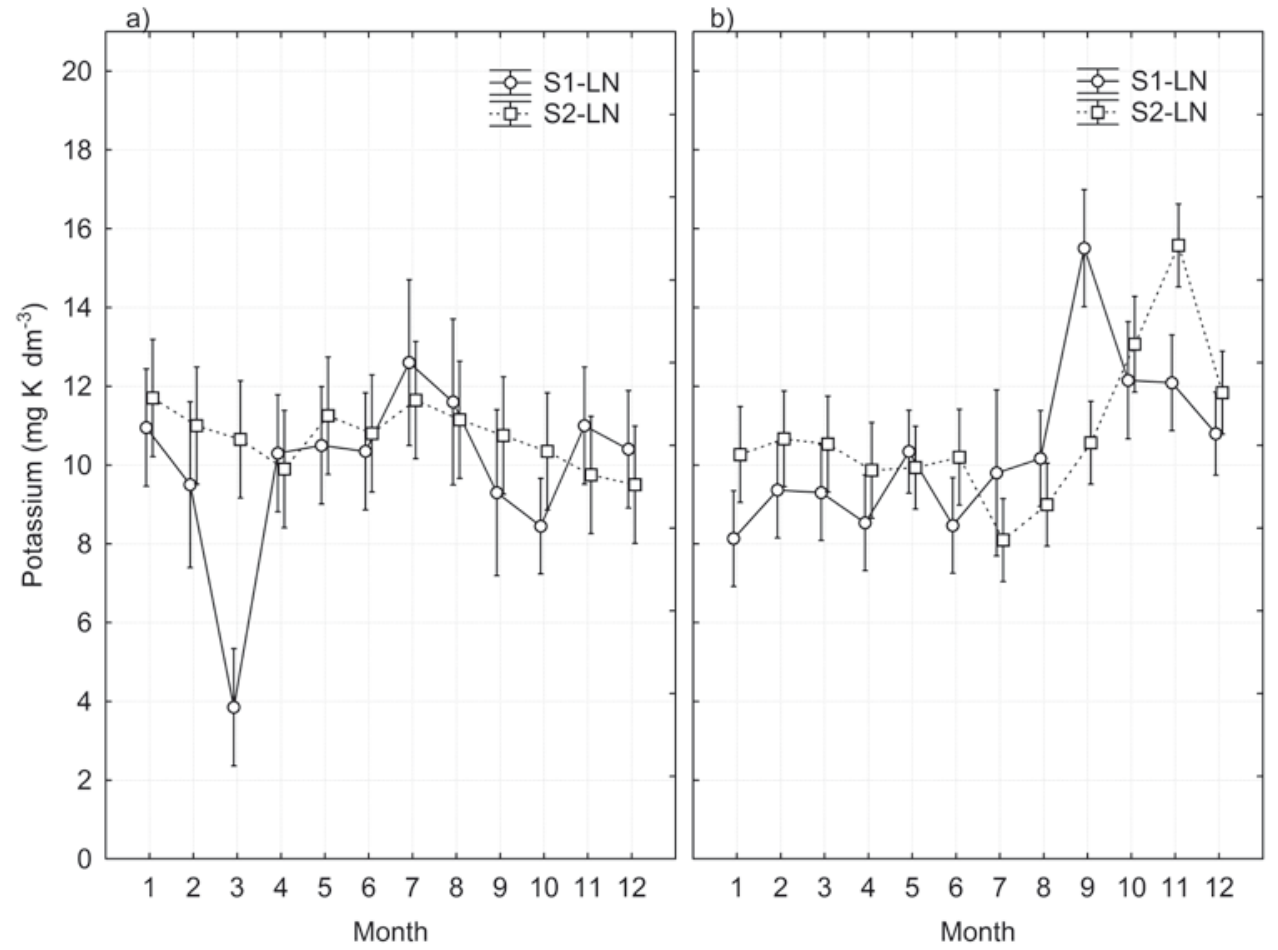

Fig. 5. Monthly potassium concentrations in the Samica Stęszewska River at the inflow (S1-LN) and outflow (S2-LN) of Lake Niepruszewskie during: a - high water retention, b - low water retention in Lake Niepruszewskie. The plot indicates mean value \pm standard error
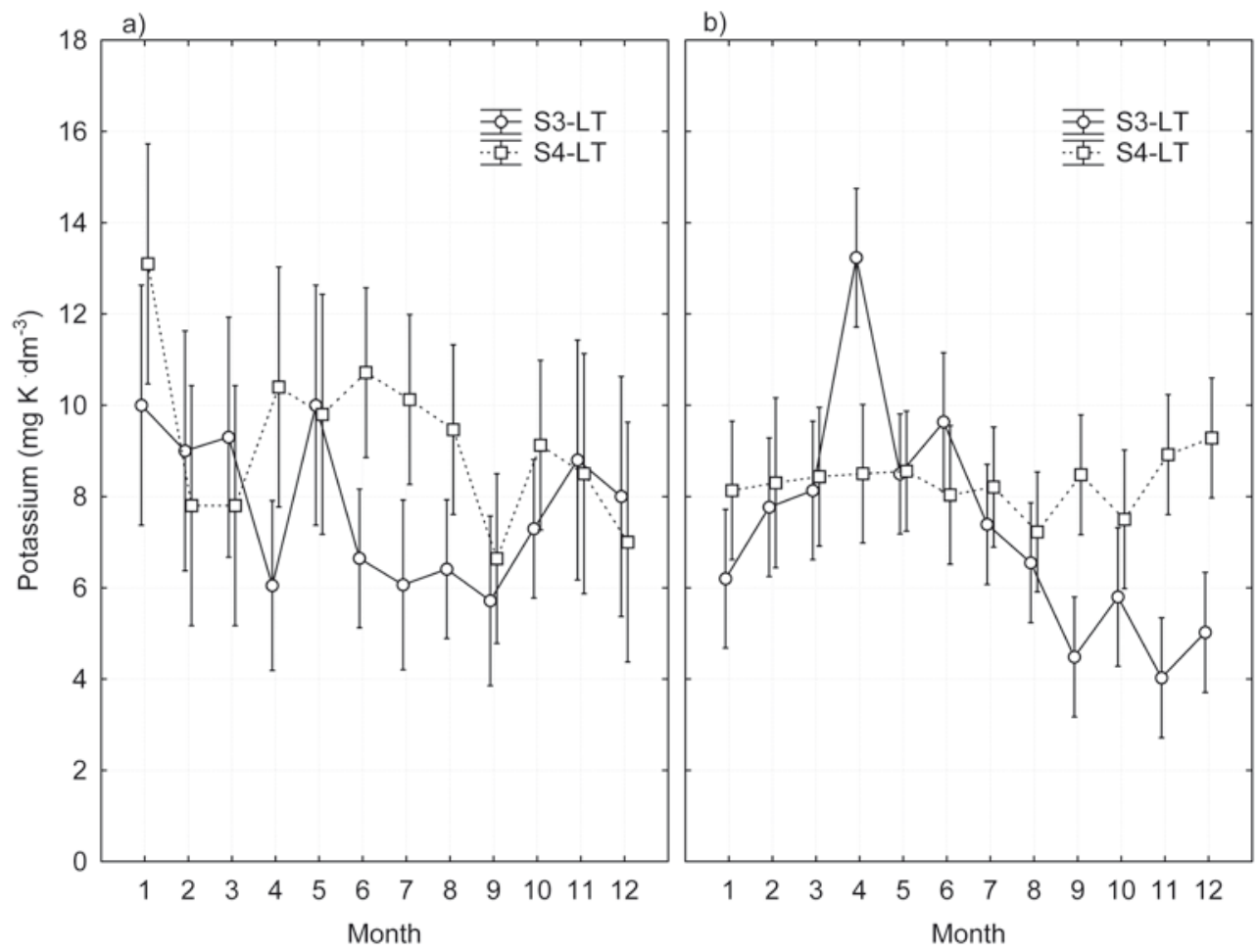

Fig. 6. Monthly potassium concentrations in the Samica Stęszewska River at the inflow (S3-LT) and outflow (S4-LT) of Lake Tomickie during: a - high water retention, b- low water retention in Lake Niepruszewskie. The plot indicates mean value \pm standard error 
stored phosphorus was observed also during storms in the autumn to spring period (Bowes et al. 2003).

Reduction in water level fluctuations had a slight impact on reactive phosphorus. The most significant differences in reactive phosphorus concentrations were measured in the inflow to Lake Niepruszewskie though they did not depend on changes in water level fluctuations but probably on meteorological conditions or fluxes from agricultural and various effluent sources in the upper part of the catchment (Bowes et al. 2003).

Opposite relationships were observed between the inflow and outflow of Samica Stęszewska to and from Lake Tomickie, respectively, where highest concentrations of total phosphorus were measured downstream. Lake Tomickie is characterized by very eutrophic stage with intensive algae bloom (Ławniczak et al. 2009). Reductions in water level fluctuations in Lake Niepruszewskie influenced water discharge of Samica Stęszewska River, and probably exacerbated water quality in Lake Tomickie (Ławniczak et al.2009), especially that from August to December 2005-2008, the lake played a role as a nutrient source for the Samica Stęszewska River. These results confirm the study of Hillbricht-Ilkowska (1999) who observed, in the stagnation period, acceleration of phosphorus export downstream. Also, shallow lakes with intensive hydrodynamic conditions have a lower buffering capacity to remove and bond phosphorus in the sediment, particularly in the presence of very high amounts of sediment deposition (Sly 1994).

Potassium concentrations downstream from Lake Niepruszewskie increased during stagnation period, probably due to the decomposition process and leaching of nutrients from the shoot parts by rain or water flow. The most significant differences occurred at the inlet to Lake Tomickie. During vegetation season, potassium concentrations did not vary significantly, but during the stagnation period decreased $\mathrm{K}$ concentrations were observed. At this site, the river flows through the forest, and aquatic vegetation in the channel is not very well developed due to significant shading of trees. These conditions may explain differences between the analysed sites. However, the detected K concentrations in the Samica Stęszewska River at all sites indicated eutrophic water quality comparable to rivers in a lowland agricultural region (Howden et al. 2009).

\section{Conclusions}

Our study revealed that $\mathrm{P}$ and $\mathrm{K}$ rates were very patchy, strongly dependent on the location within lake-river systems, and seasonally varied within years. Changes in water level fluctuations had a significant influence on water quality in the river, although this influence was not observed with respect to potassium concentrations. By considering lakes and streams together, our study confirmed that nutrient concentrations in river strongly depended on water quality of the lake ecosystem and their buffering capacity. Additionally, by improving water quality, increasing oxygen concentrations and decreasing dissolved nutrient concentrations and increasing the amplitude of water level fluctuations in lakes P-fixation rates in outlet streams may be increased.

\section{Acknowledgments}

This research was supported by Grants contract number N N305 055234 from the Ministry of Science and Higher Education (study carried out in 2008), number 2 P06S 02628 - from the Ministry of Science and Informatization (for data collected in 2005-2006) and funded by the Poznan University of Life Sciences (data collected from 1999-2001). The authors are also grateful for analytical assistance provided by Barbara Andrzejewska. We also thank the Department of Agricultural Chemistry, Poznan University of Life Sciences to allow measurements of potassium concentrations.

\section{References}

Arp C.D., Gooseff M.N., Baker M.A., Wurtsbaugh W.A., 2006, Surface-water hydrodynamics and regimes of a small mountain stream-lake ecosystem, J. Hydrol. 329: 500-513.

Bowes M.J., House W.A., 2001, Phosphorus and dissolved silicon dynamics in the River Swale catchment, UK: a mass-balance approach, Hydrol. Process. 15(2): 261-280.

Bowes M.J., House W.A., Hodgkinson R.A., 2003, Phosphorus dynamics along a river continuum, Sci. Total Environ. 313: 199-212.

Bowes M.J., Hilton J., Irons G.P., Hornby D.D., 2005, The relative contribution of sewage and diffuse phosphorus sources in the River Avon catchment, southern England: implications for nutrient management, Sci. Total Environ. 344: 67-81.

Hillbricht-Ilkowska A., 1999, Shallow lakes in lowland river systems: Role in transport and transformations of nutrients and in biological diversity, Hydrobiologia 408/409: 349-358. 
Howden N.J.K., Bowes M.J., Clark A.D.J., Humphries N., Neal C., 2009, Water quality, nutrients and the European union's Water Framework Directive in a lowland agricultural region: Suffolk, south-east England, Sci. Total Environ. 407: 2966-2979.

Kling G.W., Kipphut G.W., Miller M.M., O’brien W.J., 2000, Integration of lakes and streams in a landscape perspective: the importance of material processing on spatial patterns and temporal coherence, Freshwater Biol. 43: 477-497.

Ławniczak A.E., 2010, The role of emergent macrophytes in nutrient cycling in Lake Niepruszewskie (western Poland), Oceanol. Hydrobiol. Stud. 39(2): 75-83.

Ławniczak A.E., Zbierska J., Choiński A., 2009, Ocena stanu ekologicznego jezior w odniesieniu do Ramowej Dyrektywy Wodnej, Zesz. Probl. Post. Nauk Rol. 540: 55-67.

Manahan S.E. 2005, Environmental Chemistry, CRC Press, Boca Raton, p. 783.
Marcarelli A.M., Wurtsbaugh W.A., 2007, Effects of upstream lakes and nutrient limitation on periphytic biomass and nitrogen fixation in oligotrophic, subalpine streams, Freshwater Biol. 52: 2211-2225.

Murphy J., Riley J.P., 1962, A modified single solution method for the determination of phosphorus in natural waters, Anal. Chem. Acta 12:31-36.

Neal C., Jarvie H.P., Love A., Neal M., Wickham H., Harman S., 2008, Water quality along a river continuum subject to point and diffuse sources and canal water interchange. J. Hydrol. 350(3-4): 154-65.

Sly P.G., 1994, Sedimentary processes in lakes, [in:] P. Kenneth (ed.), Sediment transport and depositional processes, Blackwell Scientific Publ., Oxford: 157-191.

Zbierska J., Ławniczak A.E., 2006, Wpływ jezior przepływowych na jakość wody w rzece Samicy Stęszewskiej (Impact of through-flow lakes on the quality of water in the Samica Stęszewska River), Zesz. Nauk. AR Krak., Inżynieria Środowiska 433: 7-15. (in Polish, English summary). 